\title{
Antimicrobial- and Anticarcinogenic Activities of Amphitrite albicostatu Fractions
}

\author{
Hye-Jung Shin and Mi-Ok Shin* \\ Department of Food and Nutrition, Silla University, Busan 617-736, Korea
}

Received July 13, 2010 /Accepted September 13, 2010

\begin{abstract}
In this study, we investigated antimicrobial- and anticarcinogenic activities of Amphitrite albicostatu (AA) fractions. AA was extracted with methanol first and then further fractionated into four different types: hexane (AAMH)-, methanol (AAMM)-, buthanol (AAMB)- and aqueous (AAMA) partition layers. In the paper disk test, the antimicrobial activity of AA fractions increased in proportion to concentration. Among the various solvent fractions, only AAMB showed antimicrobial activity. We also determined the growth inhibition and quinone reductase $(\mathrm{QR})$ induced effects of $\mathrm{AA}$ fractions on cancer cells. The growth inhibition effects of AA fractions on HepG2 and B16F10 cells were evaluated by MTT assay. AAMM showed the strongest growth inhibition effects on HepG2 and B16F10 cells. The quinine reductase (QR) induced effects of AAMM on HepG2 cells at $100 \mathrm{ug} / \mathrm{ml}$ concentration indicated it to be 2.04 times higher than the control values of 1.0. Although further studies are needed, the present work suggests that Amphitrite albicostatu (AA) could have a potential use as a food preservative and chemopreventive agent.
\end{abstract}

Key words : Amphitrite albicostatu (AA), antimicrobial activities, anticarcinogenic activities, quinone reductase $(\mathrm{QR})$

\section{서 론}

최근 심장병, 고혈압 등의 심혈관계 질환과 더불어 사망의 주원인이 되고 있는 암은 사회의 현대화와 함께 유전적 요소 를 포함한 여러 환경적 요소가 원인으로 더욱더 발암이 증가 되고 있다. 그 중 암 발생이 식습관과 관련된 환경요인과 깊은 연관성이 있다고 알려지면서, 식이 요인의 중요성이 크게 지 적되고 있다[13,14]. 또한 암 발병률이 식이의 영양학적 요인에 의해 달라질 수 있다는 연구 결과와 더불어 식이를 조절하여 암 발생을 억제하는 암 예방에 대한 관심도 높아지고 있다. 암 예방이란 발암 과정의 초기 단계에서 암 발생을 예방하거 나 억제시키며, 암으로 진행된 것을 전환시키는 것을 의미한 다[3]. 따라서 최근에는 식이와 관련된 암의 원인물질을 검색 하는 연구가 활발히 진행되고 있으며 천연물 대체요법 등 새 로운 암 예방 물질의 개발로 예방과 치료의 방향이 전환되고 있는 실정이다[23]. 특히 천연물이나 천연물 유래의 중간화합 물은 주로 공격적인 암세포들의 증식을 막거나 약화시켜 예방 하는데 사용되고 있으며, 이들 물질의 동정과 활성 여부의 판 단 및 그 대체요법의 성공 등은 천연물을 이용한 생물학적 기초를 형성하는데 크게 기여하고 있는 실정이다[5,22]. 또한 소비자들의 식품첨가물에 대한 관심도가 높아짐에 따라 합성 보존제의 안전성 문제로 인한 기피현상이 나타나고 있어 인체 에 무해한 천연물 유래의 항균제 개발 또한 절실히 요구되고

\section{*Corresponding author}

Tel : +82-51-999-6272, Fax : +82-51-999-5457

E-mail : shinmo@silla.ac.kr
있다. 천연항균물질 중에는 전통적으로 사용해 온 소금, 식초 등 일반식품 소재 외에도 동물, 식물, 미생물 등에서 유래한 천연물질이 많이 보고되고 있다. 현재 상품화되어 있거나 항 균성이 알려진 천연물질로는 주로 lysozyme, polylysine, protamine, conalbumin, avidin, 유기산, polyphenol 물질 등 이 대표적이다[2,11].

한편, 최근에는 천연소재로서 해양생물에 대한 관심이 증대 되고 있다. 해양생물은 육상생물과 다르게 내압, 내염 및 저온 이라는 특수한 환경에서 서식하기 때문에 물리적 방어능력이 부족한 해양생물들이 적자생존의 경쟁 속에서 살아남기 위하 여 만들어내는 이차 대사산물은 육상생물과는 상이한 화학적 특성을 갖고 있는 경우가 많아 천연자원에서 의약품 등의 생 리활성물질을 탐색하여 개발하고자 하는 노력이 활발히 진행 되고 있다[17]. 본 연구에 사용된 따개비(barnacle: amphitrite albicostatu)는 갑각강 완흉목에 속하는 절지동물로 굴등 이라 고도 불리우며, 몸길이가 10-15 mm 정도인 작은 종과 30-40 $\mathrm{mm}$ 의 대형 종에 이르기 까지 그 종류가 다양하여 약 200여 종에 이른다. 세계 전 연안에 널리 분포하고 우리나라에서는 남해안에서 매우 흔하며 조간대의 중조대부터 저조대에 분포 한다. 주로 바닷가 암초나 말뚝, 배 밑 등에 무리를 이루어 비교적 단단하게 붙어서 고착생활을 하며 노출된 암반에서 쉽게 관찰된다. 단단한 껍질로 둘러싸여 있어 연체동물로 착 각하기 쉬우나 게, 새우와 같은 갑각류에 속한다. 특히, 따개비 는 남해안 도서지방에서 전복과 비슷한 맛과 영양을 가졌다 하여 값비싼 전복을 대신하여 죽, 국, 칼국수, 비빔밥 등에 많 이 사용되고 있다. 가장 흔하게 볼 수 있는 갑각류 임에도 불구 
하고 현재까지 따개비에 대한 국내연구는 순수분류학적 연구 와 생물학적 오염 지표 종의 개발, 유생발생에 관한 연구 등의 몇 편의 연구가 이루어져 있을 뿐 따개비의 다양한 생리활성 물질에 대한 구체적인 연구는 거의 수행되어 있지 않은 실정 이다[9,11,26]. 따라서 본 연구에서는 갑각류인 따개비로부터 메탄올 추출물 및 순차적 용매 분획물을 얻어 항균 효과 및 항암 효과를 검토함으로써 따개비의 기능성식품 소재로써의 개발 가능성을 알아보고자 하였다.

\section{재료 및 방법}

\section{실험재료 및 시료 추출}

실험에 사용된 따개비(Amphitrite albicostatu, AA)는 2009 년 3월 부산 기장시장에서 구입하여 깨끗이 세척한 후 동결 건조 후 분쇄하여 시료와 메탄올을 1:5(W/V)의 비율로 첨가 한 후 상온에서 2회 추출하고, 극성과 비극성으로 선별물질 을 추출하기 위하여 우선 메탄올과 다이클로로메탄 $\left(\mathrm{CH}_{2} \mathrm{Cl}\right)$ 을 1:1로 섞은 용액에 2회 추출한 후 회전식 진공농축기로 일 정시간 감압 농축시켜 동결 건조한 후 따개비의 methanol추 출물(AAM)을 얻었다. 이 추출물을 hexane층(AAMH), methanol층(AAMM), butanol층(AAMB) 및 aqueous층 (AAMA)으로 나누어 비극성에서 극성으로 계통 분획하고 각 분획층을 감압 농축 후 동결 건조하여 분말로 만들어 시 료로 사용하였다.

\section{사용 균주 및 배지}

본 실험에 사용한 균주는 Staphylococcus aureus (ATCC 25923), E-coli (ATCC 21990), Salmonella enteritidis (ATCC 13076) 및 Proteus mirabilis (ATCC 25933) Proteus valraris (ATCC 13315) 균이었으며 각 균의 생육 및 보존을 위해 사용 한 배지는 Nutrient agar (Difco), Yeast extract, Malt extract를 사용하였다.

\section{항균활성 측정}

분획된 따개비 추출물의 항균력 검색은 paper disc method 를 사용하였다[4]. 항균성 시험용 평판배지는 멸균 후 petri dish에 $20 \mathrm{ml}$ 씩 분주하여 응고시키고 전 배양한 각종 시험균 을 무균적으로 첨가하여 기층용 배지 위에 다시 $10 \mathrm{ml}$ 씩 분주 하여 이중의 평판배지를 만들었다. 각 용매 분획 별 추출물의 농도를 $500 \sim 2,000 \mu \mathrm{g} / \mathrm{ml}$ 로 하여 멸균된 disc (직경 $8 \mathrm{~mm}$, Toyo Roshi Kaisha, Ltd., Japan)에 흡수, 건조시켜 균주가 도 말 된 plate 표면에 올려놓은 후 $37^{\circ} \mathrm{C}$ incubator에서 24시간 배양하여 disc 주위에 생성된 clear zone의 직경 $(\mathrm{mm})$ 으로 부 터 각 분획물의 항균활성을 측정하였으며 실험을 5 회 반복하 여 평균치를 나타내었다.

\section{암세포 배양}

본 실험에 사용된 암 세포주는 인체 간암세포주인 HepG2 (human hepatocellular carcinoma)와 마우스 유래의 피부암세 포주인 B16-F10 (mouse melanoma)을 한국 세포주 은행 (Korean Cell Line Bank, KCLB)에서 구입하여 배양시킨 후 실험에 사용하였다. $\mathrm{HepG} 2$ 와 $\mathrm{B} 16 \mathrm{~F} 10$ 의 각 세포주는 $37^{\circ} \mathrm{C}, 5 \%$ $\mathrm{CO}_{2}$ 조건하에서 배양하였고, 주 2-3회 정도 배지를 교환하고 세포배양용 petridish에 각 세포주가 $5 \times 10^{4}$ cells $/ \mathrm{ml}$ 정도 증식 되면 phosphate buffered saline (PBS)로 2번 세척한 후 trypsin-ethylenediamine tetraacetic acid (EDTA, Gibco)를 2 ml씩 처리하여 바닥에서 세포를 분리한 후, 배지로 세포가 골고루 분산되도록 희석하여 세포배양용 petridish에 $10 \mathrm{ml}$ 씩 분할하 여 주입하고 주 2회 계대 배양하면서 실험에 사용하였다. 계대 배양 시 각 세포주의 passage number가 10회 이상일 때는 액 체질소탱크로부터 새로운 세포를 꺼내어 다시 배양하여 실험 하였다.

\section{암세포 증식 억제 효과(Cytotoxicity) 측정}

분획물의 암세포 증식 억제 효과는 MTT (3-[4,5-dimethyl thiazol-2-yl]-2,5-diphenyltetrazolium bromide) assay를 사용 하여 행하였다. MTT assay $[1,12]$ 는 세포의 생육을 측정하는 방법으로서 황색수용물질인 MTT가 미토콘드리아내의 탈수 소효소 작용에 의하여 dark blue formazan을 생성하는 원리를 이용한다. 이를 위해 각 세포주를 $1 \times 10^{4}$ cells/well의 농도로 맞추고 96 well에 각각 $200 \mu 1$ 씩 첨가하여 24 시간 동안 $37^{\circ} \mathrm{C}$, $5 \% \mathrm{CO}_{2}$ incubator에서 배양한 후 용매종류별 분획물을 각각 일정량의 dimethyl-sulfoxide (DMSO)에 녹여서 50, 100, 150, $200,250 \mu \mathrm{g} / \mathrm{ml}$ 의 농도로 첨가하였다. 48시간 동안 배양한 후 각 well에 PBS 완충용액에 녹인 MTT 용액을 $20 \mu \mathrm{ll}$ 씩 첨가하여 4 시간 동안 다시 배양시킨 후, well 바닥에 형성된 formazan이 흩어지지 않게 상등액을 제거하고 DMSO와 ethanol을 1:1로 혼합한 용액 $200 \mu 1$ 를 첨가하여 천천히 녹인 후 Multi-detection microplate를 이용하여 $540 \mathrm{~nm}$ 에서 흡광도를 측정하 였다. 대조군 세포수를 $100 \%$ 로 하였을 때의 상대적인 세포 증식 억제 율을 구하였다.

\section{Quinone reductase (QR) 유도 활성 측정}

Quinone reductase는 phase $\Pi$ 무독화 효소중의 하나로 돌 연변이 되는 발암물질 등에 의한 $\mathrm{DNA}$ 와의 상호 작용을 차단 하는 효소이며, $\mathrm{NAD}(\mathrm{P}) \mathrm{H}$ 를 이용하여 quinone류의 환원을 촉 매하는 flavoprotein이다[16,27].

본 실험에서는 Prochaska와 Santamaria의 방법[18]을 일부 변형하여 측정하였다. 세포배양용 petridish에 HepG2 세포가 $80 \%$ 이상 증식하게 되면 24 well plate의 각 well에 $1 \times 10^{4}$ cells $/ \mathrm{ml}$ 되도록 세포를 분주하여 $37^{\circ} \mathrm{C}, 5 \% \mathrm{CO}_{2}$ incubator에 서 24시간 동안 배양한 후 따개비 분획물을 HepG2의 세포생 
존율이 $50 \%$ 되는 양을 final 농도로 잡아 각각 $\mathrm{DMSO}$ 에 녹여 $20,40,60,80,100 \mu \mathrm{g} / \mathrm{ml}$ 의 농도로 첨가하고 다시 24 시간 배양 하였다. 배양액을 제거한 후 각 well에 $250 \mu \mathrm{l}$ 의 lysis buffer (10 mM Tris- $\mathrm{HCl} \mathrm{pH}$ 8.0, $14 \mathrm{mM} \mathrm{NaCl}, 15 \mathrm{mM} \mathrm{MgCl}$, 0.5\% $\mathrm{NP}-40$ )를 첨가한 후 $37^{\circ} \mathrm{C}, 5 \% \mathrm{CO}_{2}$ incubator에 10 분간 두면서 cell을 lysis한 후 reaction mixture 즉, $10 \mathrm{mM}$ Tris- $\mathrm{HCl}(\mathrm{pH}$ 7.4), $0.5 \mathrm{mg} / \mathrm{ml}$ BSA, $0.008 \%$ tween-20, $40 \mu \mathrm{M}$ FAD, $0.8 \mathrm{mM}$ glucose-6-phosphate, 2 Unit/ml glucose-6-phosphate dehydrogenase, $25 \mu \mathrm{M}$ NADP, $40 \mu \mathrm{g} / \mathrm{ml}$ MTT 및 $1 \mathrm{mM}$ menadione을 혼합하여 well에 $1 \mathrm{ml}$ 씩 첨가하여 5분 동안 반응시킨 후, 반응정지 용액인 $0.3 \mathrm{mM}$ dicumarol, $0.5 \%$ pyridine, $5 \mathrm{mM}$ potassium phosphate (pH 7.4) 혼합액을 $250 \mu \mathrm{l}$ 씩 첨가하여 효소반응을 정지시키고 Multi-detection microplate를 이용하 여 $610 \mathrm{~nm}$ 에서 흡광도를 측정하여 계산하였다.

단백질량은 동일한 set의 well plate에 대한 crystal violet 염색방법으로 정량 하였다. 24 well plate에 crystal violet 용액 을 첨가하고 $37^{\circ} \mathrm{C}, 5 \% \mathrm{CO}_{2}$ incubator에서 배양한 후 증류수로 세척하였다. 각 well에 $0.5 \% \mathrm{SDS}$ (in $50 \% \mathrm{EtOH}$ ) 용액을 $1 \mathrm{ml}$ 씩 가하여 $37^{\circ} \mathrm{C}, 5 \% \mathrm{CO}_{2}$ incubator에서 1시간 방치한 후 610 $\mathrm{nm}$ 에서 흡광도를 측정하였다. Quinone reducatse 활성측정 $(\mathrm{nmol} / \mathrm{min} / \mathrm{mg}$ protein)은 다음과 같이 하였다.

$\begin{gathered}\text { Quinone reducatse } \\ (\mathrm{QR}) \text { activity }\end{gathered}=\frac{\text { absorbance change of MTT } / \mathrm{min}}{\text { absorbance of crystal violet }} \times 3345 \mathrm{nmol} / \mathrm{mg}$

\section{통계처리}

본 실험에 대한 실험결과는 세 번 실험하여 얻어진 평균치 및 표준편차를 나타내었고, 그룹간의 통계적 차이는 student's t-test를 이용하여 분석하였다.

\section{결과 및 고찰}

\section{추출물 및 분획물의 수율}

따개비 건조 분말 시료를 methanol로 2회, dichloromethane과 ethanol을 1:1로 섞은 용매에 2회 추출하여 추출물 (AAM) $23.63 \mathrm{~g}$ 을 얻고, 이 추출물을 용매 별로 분획하여 hexane (AAMH) $1.03 \mathrm{~g}$, methanol (AAMM) $0.34 \mathrm{~g}$, butanol (AAMB) $0.68 \mathrm{~g}$ 및 aqueous (AAMA) $11.07 \mathrm{~g}$ 을 얻었다. 순차 적 분획물의 수율은 Table 1 에 나타내었다.

\section{항균 활성}

따개비 분획물을 식중독 원인균인 Staphylococcus aureus (ATCC 25923), E-coli (ATCC 21990) 및 Salmonella enteritidis (ATCC 13076)와 단백질 부패 원인균인 Proteus mirabilis (ATCC 25933)의 4가지 균주에 처리하여 항균 활성을 조사한 결과는 Table 2 와 같다. 4 가지 균주 모두 부탄올 분획층인 $\mathrm{AAMB}$ 층에서만 항균활성이 나타났으며, 다른 분획층에서는
Table 1. Yield of each fractions extracted from Amphitrite albicostatu

\begin{tabular}{lcc}
\hline Fraction & Yield $(\mathrm{g})$ & Yield $(\%)$ \\
\hline Methanol extract (AAM) & 23.63 & 4.69 \\
Hexane fr. (AAMH) & 1.03 & 4.36 \\
Methanol fr. (AAMM) & 0.34 & 1.44 \\
Butanol fr. (AAMB) & 0.68 & 2.88 \\
Aquous fr. (AAMA) & 11.07 & 46.85 \\
\hline
\end{tabular}

유의성 있는 항균 활성 효과를 볼 수 없었다. 각 균주 별로 살펴보면 식중독 원인균인 Staphylococcus aureus의 경우 $\mathrm{AAMB}$ 층에서 시료 첨가 농도를 $500,1,000,1,500$ 및 2,000 $\mathrm{kg} /$ $\mathrm{ml}$ 로 처리하였을 때 농도 의존적으로 항균 활성이 증가하였으 며, 각각 6.0, 10.3, 13.0 및 $15.5 \mathrm{~mm}$ 의 clear zone을 나타내어 실험에 사용된 다른 3 균주에 비해 가장 높은 항균 활성 효과 를 볼 수 있었다. 다음으로 대장균인 E. coli 균의 경우에서도 역시 $\mathrm{AAMB}$ 층에서만 유의성 있는 항균 활성 효과를 볼 수 있었으며 $1,000,1,500$ 및 $2,000 \mu \mathrm{g} / \mathrm{ml}$ 첨가 농도에서 각각 7.3 , 10.1 및 $11.0 \mathrm{~mm}$ 의 clear zone을 나타내었다. 또한 Salmonella enteritidis와 Proteus mirabilis의 경우에서도 역시 AAMB층에 서만 유의성 있는 항균 활성 효과를 볼 수 있었으며, 최종 농도 인 $2,000 \mu \mathrm{g} / \mathrm{ml}$ 첨가 농도에서 $10.8 \mathrm{~mm}$ 와 $10.7 \mathrm{~mm}$ 의 항균 활성 효과를 나타내었다. 이상의 결과로 따개비 분획물은 모 든 균주에 부탄올 분획층인 $\mathrm{AAMB}$ 층에서 가장 높은 항균 활 성을 나타냄을 알 수 있었다. 앞으로 항균활성을 나타내는 부 탄올 분획층에서의 항균 활성 물질을 규명하여 이들 활성 성 분을 이용한 천연 항균 식품 보존제등의 기능성소재로서의 개발이 기대되어진다.

\section{따개비 분획물의 암세포 증식 억제 효과}

간암세포주인 HepG2와 피부암세포주인 B16-F10를 사용하 여 MTT assay를 측정 하여 따개비 분획물의 암세포 증식 억제 효과를 알아보았으며 그 결과는 Fig. 1과 Fig. 2에 나타내었다. Fig. 1은 HepG2에 따개비 분획물을 50, 100, 150, 200 및 250 $\mu \mathrm{g} / \mathrm{ml}$ 의 농도로 증가시켜 첨가했을 때의 암세포 증식 억제 효과를 나타낸 그림으로, 다른 분획층에 비해 메탄올 분획층 인 $\mathrm{AAMM}$ 층에서 가장 높은 암세포 증식 억제 효과를 나타내 었다. 즉 $250 \mu \mathrm{g} / \mathrm{ml}$ 의 최종 첨가 농도에서 $96.38 \%$ 의 암세포증 식 억제효과를 나타내었고, 다음으로 AAMA층, AAMB층 및 $\mathrm{AAMH}$ 층의 순으로 암세포증식 억제 효과를 나타내었다. 그 리고 AAMA층의 경우는 최종 첨가 농도인 $250 \mu \mathrm{g} / \mathrm{ml}$ 에서 $57.79 \%$ 의 암세포 증식 억제 효과를 나타내었다 그러나 $\mathrm{AAMB}$ 층과 $\mathrm{AAMH}$ 층에서는 암세포 증식 억제 효과가 농도 의존적 으로는 나타났으나, 그 효과는 $40 \%$ 이하로 아주 미약하였다. Fig. 2는 B16-F10에 대한 암세포 증식 억제 효과에 대한 실험결 과이며 HepG2에서의 결과와 같이 메탄올 분획층인 $\mathrm{AAMM}$ 
Table 2. Antibacterial activities of extracts and each solvent fraction from albicostatu against bacteria

\begin{tabular}{|c|c|c|c|c|c|}
\hline \multirow[t]{2}{*}{ Fractions ${ }^{1)}$} & \multicolumn{5}{|c|}{ Clear zone on plate $(\mathrm{mm})^{2)}$} \\
\hline & $\mathrm{mg} / \mathrm{ml}$ & AAMA & AAMB & AAMH & AAMM \\
\hline \multirow{4}{*}{ Staphylococcus aureus } & 0.5 & - & - & - & - \\
\hline & 1.0 & - & +++ & - & - \\
\hline & 1.5 & - & ++++ & - & - \\
\hline & 2.0 & - & ++++ & - & - \\
\hline \multirow{4}{*}{ E-coli } & 0.5 & - & - & - & - \\
\hline & 1.0 & - & ++ & - & - \\
\hline & 1.5 & - & +++ & - & - \\
\hline & 2.0 & - & ++++ & - & - \\
\hline \multirow{4}{*}{ Salmonella enteritidis } & 0.5 & - & - & - & - \\
\hline & 1.0 & - & + & - & - \\
\hline & 1.5 & - & +++ & - & - \\
\hline & 2.0 & - & ++++ & - & - \\
\hline \multirow{4}{*}{ Proteus mirabilis } & 0.5 & - & - & - & - \\
\hline & 1.0 & - & - & - & - \\
\hline & 1.5 & - & +++ & - & - \\
\hline & 2.0 & - & ++++ & - & - \\
\hline
\end{tabular}

${ }^{1)}$ AAMH: Hexane partition layer of AAM, AAMB: Butanol partition layer of AAM, AAMM: Methanol partition layer of AAM, AAMA: Aqueous layer of methanol extracts Amphitrite albicustatu (AAM)

${ }^{2)}$ Treated sample was absorbed into paper disc $(6 \mathrm{~mm}$, diameter) and the Diameter $(\mathrm{mm})$ of clear zone was confirmed around the colony.

Growth inhibition size of clear zone: ++++ , larger than $10.5 \mathrm{~mm} ;+++, 10.5 \sim 9.0 \mathrm{~mm}:++, 7.5 \sim 9.0 \mathrm{~mm} ;+$, smaller than $7.5 \mathrm{~mm}$; -, not detected.

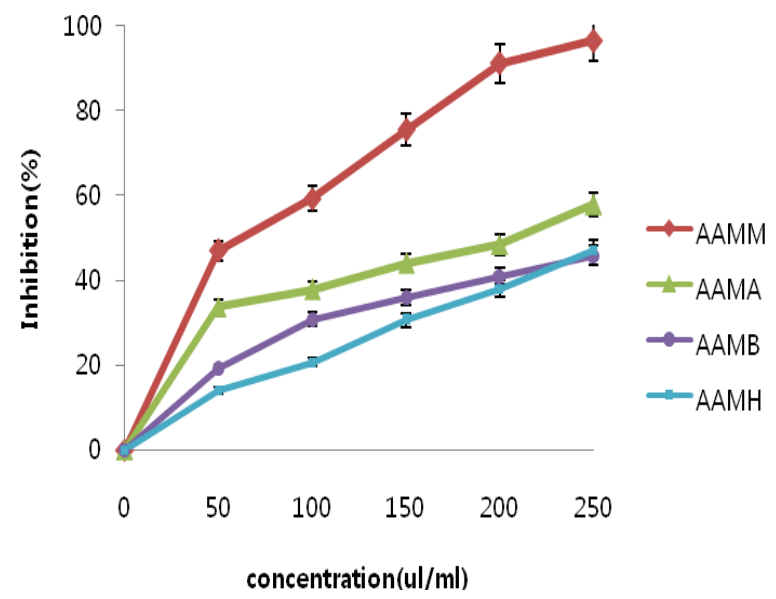

Fig. 1. Inhibitory effect on cell survival of various partition layers of Amphitrite albicostatu in HepG2 cells.

층에서 가장 높은 암세포 증식 억제 효과를 나타내었으며, 최 종농도인 $250 \mu \mathrm{g} / \mathrm{ml}$ 의 농도에서 $79.14 \%$ 의 높은 암세포 증식 억제효과를 나타내었다. 그리고 역시 HepG2에서의 결과와 같 이 $\mathrm{AAMA}$ 층, $\mathrm{AAMB}$ 층 및 $\mathrm{AAMH}$ 층의 순으로 암세포증식 억제 효과를 나타내었다. 그러나 $\mathrm{AAMM}$ 층을 제외한 다른 분 획층인 $\mathrm{AAMA}, \mathrm{AAMB}$ 및 $\mathrm{AAMH}$ 층에서는 $40 \%$ 이하의 낮은 암세포 증식 억제효과를 나타내었다.

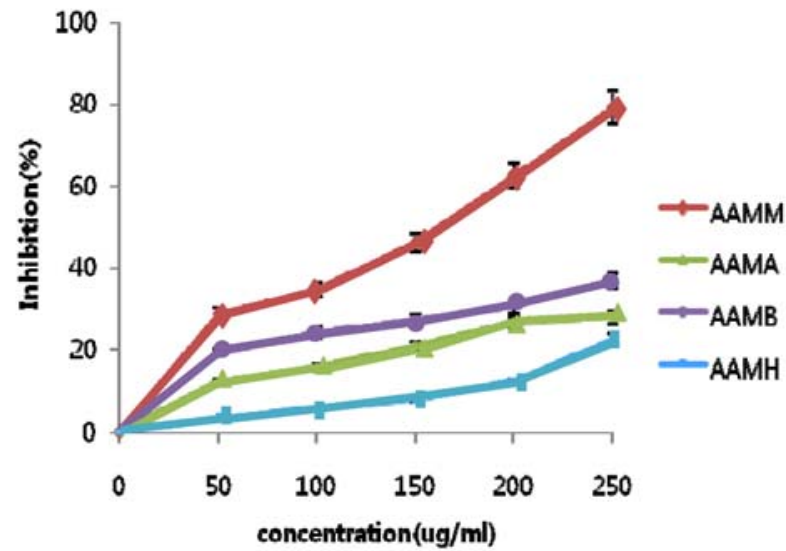

Fig. 2. Inhibitory effect on cell survival of various partition layers of Amphitrite albicostatu in B16F10 cells.

이상의 결과에서 HepG2와 B16-F10 세포주에 미치는 암세 포 증식 억제 효과는 따개비 분획물의 메탄올 분획층인 $\mathrm{AAMM}$ 층에서 그 효과가 가장 뚜렷하게 나타났다. 따라서 암 세포 증식 억제를 일으키는 따개비의 생리 활성 물질은 비극 성물질이 녹아있는 메탄올 분획층인 $\mathrm{AAMM}$ 층에 주로 많이 존재한다고 추측해 볼 수 있었다. 이와 같은 결과는 본 실험실 에서 연구되어진 키조개, 참치지느러미 등의 해양 동물과 대 부분의 해조류가 모두 메탄올 분획물에서 가장 높은 암세포 
성장 억제 효과를 나타낸 결과 $[8,17,24,25]$ 와 유사한 결과이다. 앞으로 $\mathrm{AAMM}$ 층에서의 암세포 성장을 저지하기 위한 기능성 물질의 존재가 기대되어지며 더욱더 심도 있는 연구를 통해 생리 활성물질들을 규명하고 구조와 그 기전들을 알아보는 연구가 진행되어야 한다고 생각된다.

\section{Quinone reductase 유도 활성 효과}

phase $\Pi$ 효소계의 지표효소인 quinone reductase $(\mathrm{QR})$ 는 돌연변이 또는 발암물질 등에 의한 DNA와의 상호작용을 차 단하는 효소로서 $\mathrm{NAD}(\mathrm{P}) \mathrm{H}$ 를 이용하여quinone 류의 환원을 촉매하고, 활성부위에 flavin adenine dinucleotide (FAD)를 함유하는 flavoprotein이다. 특히 $\mathrm{QR}$ 은 phase II 효소계의 지 표효소로서 다양한 종류의 항암물질에 의해 그 활성이 유도되 어 암예방을 선도하는 특성을 가지고 있어서 암 예방 물질의 탐색에 많이 사용되어 왔다[6,19,20,21].

암세포 증식 억제 효과에 사용된 암세포 중 quinone reductase를 가지고 있는 간암 세포인 HepG2 세포주를 사용하여 따개비 분획물의 $\mathrm{QR}$ 유도 활성 효과를 측정하였으며 그 결과 는 Fig. 3과 같다. HepG2 암세포주에 따개비 분획물을 첨가했 을 때, 암세포 증식 억제 효과에 대한 결과와 같이 메탄올 분획 층인 $\mathrm{AAMM}$ 층에서 가장 높은 $\mathrm{QR}$ 유도 활성 효과를 나타내었 다. 대조군을 1 로 하여 비교한 결과 20, 40, 60, 80 및 $100 \mu \mathrm{g} / \mathrm{ml}$ 의 시료 농도 첨가 시 $\mathrm{AAMM}$ 층에서 그 효과가 농도 의존적으 로 유의성 있게 증가하였으며, 각각 1.2, 1.5, 1.6, 1.8 및 2.0 배의 $\mathrm{QR}$ 유도 활성 증가 효과를 나타내었다. 다음으로 $\mathrm{AAMB}$ 층에서는 각각 $1.0,1.1,1.3,1.4$ 및 1.5 배의 $\mathrm{QR}$ 유도 활성 증가 효과를 나타내었다. 그러나 $\mathrm{AAMH}$ 층과 AAMA층에서는 유 의성 있는 $\mathrm{QR}$ 유도 활성을 볼 수 없었다. 이상의 결과에서 따개비 분획물 중 메탄올 분획층인 $\mathrm{AAMM}$ 층에서 가장 높은 $\mathrm{QR}$ 유도 활성 증가 효과를 보여 이 분획층에서 암예방 효소계 인 $\mathrm{QR}$ 의 inducer가 주로 존재함을 추정할 수 있었다. 이러한 결과는 본 연구실에서 연구된 다른 시료들과 비교해볼 때, 키 조개[18], 참치지느러미[24] 등의 대부분의 해양생물이 주로

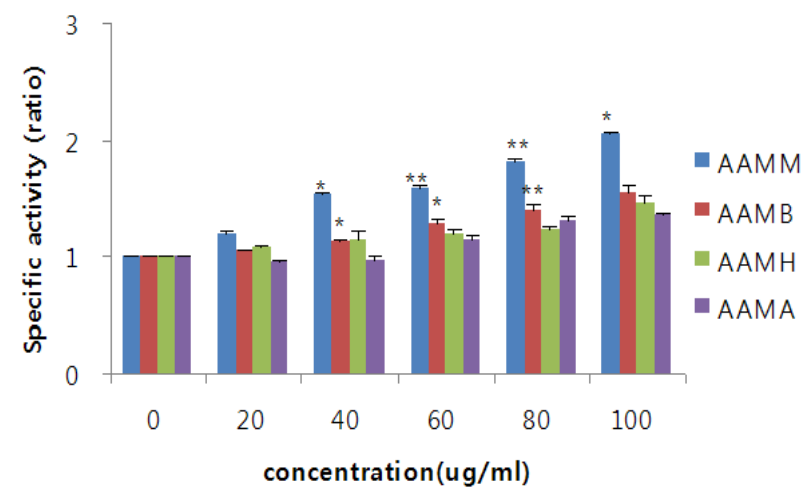

Fig. 3. Effect of various partition layers of Amphitrite albicostatu on the induction of quinone reductase in HepG2 cells.
메탄올 분획층에서 가장 높은 $\mathrm{QR}$ 활성 효과를 나타낸 결과와 일치하였으며 그 효과도 유사하였다 그러나 여러 해조류 분획 물들 $[7,9,18]$ 에 비해서는 다소 낮은 $\mathrm{QR}$ 유도 활성 효과에 해당 된다. 앞으로 더욱 더 심도 있는 연구를 통해 따개비 분획물 중 메탄올 분획층에서의 생리활성 물질을 추적, 보완하여 그 구조를 동정함으로써 식품산업에 있어서의 암 예방 효과를 지닌 기능성 식품개발에 매우 중요한 자료가 될 수 있을 것으 로 사료된다.

\section{References}

1. Carmichael, J., W. G. De Graff, A. F. Gazder, J. D. Minna, and J. B. Mitchell. 1987. Evaluation of a tetrazolium based semiautomated colorimetric assay: assessment of chemosensitivity testing. Cancer Res. 47, 936-942.

2. Cho, M. H., E. K. Bae, S. D. Ha, and J. Y. Park. 2005. Application of natural antimicrobials to food industry. Food Sci. Ins. 38, 36-45.

3. Cho, S. G. 1997. Food chemoprevention and immunoactivity. J. Food Industry and Nutr. 2, 56-101.

4. Davidson, P. M. and M. E. Parish. 1989. Methods for testing the efficacy of food antimicrobials. Food Technol. 1, 148-155.

5. Doll, R. and R. Peto. 1981. Cause of cancer: Quantitative estimates of avoidable risks of cancer in the united states today. JNCI 66, 1191-1308.

6. Hong, E. Y., H. J. Kang, C. S. Kwan, Y. J. Na, M. J. Suh, and J. S. Kim. 1997. Modulation of cellular quinone reductase inducibility by roasting treatment and acid hydrolysis of perilla. J. Korean Soc. Food Sci. Nutr. 26, 186-192.

7. Jung, B. M., S. S. Lim, Y. J. Park, and S. J. Bae. 2005. Inhibitory effects on cell surviva and quinone reductase induced activity of aster yomena fractions on human cancer cells. J. Korean Soc. Food Sci. Nutr. 34, 8-12.

8. Jung, Y. H., B. M. Jung, M. O. Shin, and S. J. Bae. 2006. A study on the effects of anticarcinogenic activity of gloiopeltis tenax. J. Korean Soc. Food Sci. Nutr. 35, 395-401.

9. Lee, C. and C. H. Kim. 1990. Lavel development of balanus albicostatus Pilsbry (Cirripedia, Thoracica) reared in the laboratory. J. Environ. Studies 8, 41-55.

10. Lee, J. H. and S. R. Lee. 1994. Some physiological activity of phenolic substances in plant foods. Korean J. Food Sci. Technol 26, 317-323.

11. Lee, J. W. and P. Chin. 2003. Development of physiological and biochemical bioindicators of barnacle, megabalanus rosa for marine pollution assessment. J. Korean Fish Soc. 36, 276-282.

12. Michael, C. A., A. S. Dominic, M. Anne, L. H. Miriam, J. C. Maciej, L. F. Donald, J. A. Betty, G. M. Joseph, H. S. Robert, and R. B. Michael. 1988. Feasibility of drug screening with panels of human tumor cell lines using a microculture tetrazolium assay. Cancer Res. 48, 589-601.

13. Ong, T. M., W. Z. Whong, S. Stewatr, and H. E. Brockman. 1986. Chlorophyllin; a potent antimutagen against environ- 
mental and dietary complex mixture. Mutat. Res. 173, 111-115.

14. Park, B. J., H. S. Suk, G. S. Chung, and J. K. Sohn. 1987. Studies on protoplast culture and fusion in cruciferae. Korean J. Breed 19, 223-234.

15. Park, H. J. 1998. Induction of quinone reductase and its regulatory mechanism at the transcriptional level by Scutellaria baicalensis, Ph. D. Thesis, Yonsei University, Seoul, Korea.

16. Park, J. C. and J. W. Choi. 1996. Screening of marine natural products on inhibitory effect of the formation of lipid peroxidation. Korean J. Pharmacol. 27, 117-122.

17. Park, S. Y., B. M. Jung, Y. H. Choi, and S. J. Bae. 2005. Growth inhibition effects of cancer cell lines by gloiopeltis furcata fractions in vitro. J. Korean Soc. Food Sci. Nutr. 34, 771-775.

18. Park, Y. J., M. O. Shin, S. H. Lee, and S. J. Bae. 2005. The growth inhibitory effects of atrina pecitinata fractions on cancer cell lines. Korean J. Nutr. 38, 307-312.

19. Prochaska, H. J. 1994. Screening strategies for the detection of anticarcinogenic enzyme inducers. J. Nutr. Biochem. 5, 360-370

20. Prochaska, H. J. and A. B. Santamaria. 1988. Direct measurement of $\mathrm{NAD}(\mathrm{P}) \mathrm{H}$ : Quinone reductase from cells cultured in microtiter wells: A screening assay for anticarcinogenic enzyme inducers. Anal. Biochem. 169, 328-336.

21. Prochaska, H. J., A. B. Santamaria, and P. Talalay. 1992.
Rapid detection of inducers of enzyme that protect against carcinogen. Proc. Natl. Acad. Sci. USA 89, 2394-2399.

22. Reddy, L., B. Odhav, and K. D. Bhoola. 2003. Natural products for cancer prevention a global perspective. Pharmacology and Therapeutics 99, 1-13.

23. Sharman, S., D. S. Jill, G. J. Kelloff, and E. S. Vernon. 1994. Screening of potential chemopreventive agents using biochemical markers of carcinogenesis. Cancer Res. 54, 58485855.

24. Shin, M. O., M. J. Ku, and S. J. Bae. 2007. Cytotoxicity and quinone reductase activity stimulating effects of fin of thunnus thynnus extracts in various cancer cells. Korean J. Nutr. 40, 147-153.

25. Shon, J. H., D. Y. Kang, H. C. OH, B. M. Jung, M. H. Kim, M. O. Shin, and S. J. Bae. 2006. The effects on antimicrobial and cytotoxicity of hijikia fusiformis fraction. J. Korean Soc. Food Sci. Nutr. 39, 444-450.

26. Sung, C. G., M. S. Choi, H. H. Chun, I. Lee, H. P. Park, and C. H. Lee. 2008. Effect of heavy metals an larvae of barnacle, balanus albicostatus. J. Environ. Toxicol. 23, 337342.

27. Steinkellner, H., S. Rabot, C. Freywald, E. Nobis, G. Scharf, M. Chabicovsky, S. Knasmuller, and F. Kassie. 2001. Effect of crucifrous vegetable and their constituents on drug metabolizing enzymes involved in the bioactivation of DNA-reactive dietary carcinogens. Mutat Res. 480, 285-297.

\title{
초록 : 따개비 분획물의 항균 및 항암 효과
}

\author{
신혜정 · 신미옥*
}

(신라대학교 식품영양학과)

본 연구에서는 갑각류에 속하는 따개비를 각 용매 별로 분획하여 항균효과, 암세포 증식 억제 및 $\mathrm{QR}$ 유도 활 성 효과를 알아보았다. 따개비의 각 분획물 $\mathrm{AAMH}, \mathrm{AAMB}, \mathrm{AAMM}$ 및 $\mathrm{AAMA}$ 층을 식중독 원인균인 Staphylococcus aureus (ATCC 25923), E.coli (ATCC 21990) 및 Salmonella enteritidis (ATCC 13076)와 단백질 부패 원인균인 Proteus mirabilis (ATCC 25933)의 4가지 균주에 처리하여 항균 활성을 조사한 결과 부탄올 분획층인 $\mathrm{AAMB}$ 층에서 가장 높은 항균 활성 효과를 나타내었다. 또한 HepG2와 B16-F10 세포주에 대한 암세포 증식 억제 효과를 알아 본 결과 메탄올 분획층인 $\mathrm{AAMM}$ 에서 높은 암세포 성장 억제 효과를 나타내었다. 그리고 quinone reductase를 가지고 있는 간암 세포인 HepG2세포주를 이용한 $\mathrm{QR}$ 유도 활성 효과의 결과에서도 암세포 성장 억 제 효과의 결과에서와 마찬가지로 메탄올 분획층인 $\mathrm{AAMM}$ 층에서 가장 높은 $\mathrm{QR}$ 유도 활성 효과를 나타내었다. 대조군을 1 로 하여 비교한 결과 $20,40,60,80$ 및 $100 \mu \mathrm{g} / \mathrm{ml}$ 의 시료 농도 첨가 시 $\mathrm{AAMM}$ 층에서 그 효과가 농도 의존적으로 유의성 있게 증가하였으며, 각각 $1.20,1.54,1.59,1.82$ 및 2.04 배의 $\mathrm{QR}$ 유도 활성 증가 효과를 나타내 었다. 따라서 본 연구결과는 앞으로 따개비를 이용한 항균, 항암관련 기능성 식품에 대한 개발 가능성이 보이며, 이를 위한 부탄올 및 메탄올 분획물에 대한 집중적인 연구가 요구되어진다. 그리고 해양 동물 중의 하나인 갑각 류에 속하는 따개비에 대한 활성 연구에 있어 기초자료가 될 것으로 예상되며, 해양생물이 크게 대두되고 있는 요즈음 유사 종의 갑각류인 새우나 게에 비해 그 활용도가 극히 낮은 따개비에 대한 소비촉진에 영향을 끼칠 것으로 기대되어진다. 